\title{
Correction to: Quantifying Topographic Characteristics of Wetlandscapes
}

\author{
Collin Branton ${ }^{1} \cdot$ Derek T. Robinson $^{1}$
}

Published online: 5 March 2020

(C) Society of Wetland Scientists 2020

\section{Correction to: Wetlands \\ https://doi.org/10.1007/s13157-019-01187-2}

The article "Quantifying Topographic Characteristics of Wetlandscapes by Collin Branton \& Derek T. Robinson was originally published electronically on the publisher's internet portal (currently SpringerLink) on June 25, 2019 without open access.

With the author(s)' decision to opt for Open Choice, the copyright of the article changed on (enter date) to (C) The Author(s) 2020 and the article is forthwith distributed under the terms of the Creative Commons Attribution 4.0 International License (http://creativecommons.org/licenses/by/ 4.0/), which permits use, duplication, adaptation, distribution and reproduction in any medium or format, as long as you give appropriate credit to the original author(s) and the source, provide a link to the Creative Commonslicence, and indicate if changes were made. The images or other third party material in this articleare included in the article's Creative Commons licence, unless indicated otherwise in a credit line to thematerial. If material is not included in the article's Creative Commons licence and your intended use isnot permitted by statutory regulation or exceeds the permitted use, you will need to obtain permissiondirectly from the copyright holder. To view a copy of this licence, visit http://creativecommons.org/licenses/by/4.0/.

The online version of the original article can be found at https://doi.org/ 10.1007/s13157-019-01187-2

Collin Branton

cebranto@uwaterloo.ca

1 Department of Geography and Environmental Management, University of Waterloo, 200 University Avenue West, Waterloo, ON N2L 3G1, Canada
Publisher's Note Springer Nature remains neutral with regard to juristional claims in published maps and institutional affiliations. 